\title{
Assessing the evidence of climate variability in the northern part of Ethiopia
}

\author{
Tagel Gebrehiwot ${ }^{1 *}$ and Anne van der Veen ${ }^{2}$ \\ ${ }^{1}$ Laboratory for Social Interactions and Economic Behaviour (LSEB), University of Twente, P. O. Box 217, \\ 7514 AE Enschede, The Netherlands. \\ ${ }^{2}$ University of Twente, P. O Box 217, 7514 AE Enschede, The Netherlands. \\ Accepted 7 February, 2013
}

\begin{abstract}
In semi-arid highlands of northern Ethiopia, episodes of droughts of varying severity and duration occur. The occurrence of these droughts is associated mainly with the seasonal rainfall variability. This study attempts to investigate the temporal and spatial variability of climate parameters, particularly rainfall and temperature for the period 1954-2008. Standardized rainfall anomaly was used to examine the temporal characteristics of climate variability and determine the prevalence of droughts. Analysis of variance was also employed to establish significant differences in rainfall characteristics amongst different in-situ stations. The baseline climate data from each station was also spatially interpolated using ordinary kriging technique. The temporal analysis indicated an overall slight decrease in rainfall and an overall increase in the mean annual minimum and maximum temperatures over the study period. The analysis further revealed that the average annual minimum temperature over the region has been increasing by about $0.72^{\circ} \mathrm{C}$ every ten years while average annual maximum temperature has been increasing by about $0.36^{\circ} \mathrm{C}$ per decade. This shows that the northern part of Ethiopia is warming faster than the national average of $0.255^{\circ} \mathrm{C}$ per decade. It is also observed that the average annual minimum temperature is increasing faster than average annual maximum temperature, which is an indication of warming nights over the years.
\end{abstract}

Key words: Weather, variability, drought, rainfall, temperature.

\section{INTRODUCTION}

Changes in temperature and rainfall patterns are widely observed in many semi-arid parts of the developing world that are likely to become even hotter and dryer with time (Collier et al., 2008). Recent observational and modelling studies showed that the warmest temperature extremes, particularly those derived from minimum temperature, have significantly increased over the 20th century and will continue to increase throughout the $21 \mathrm{st}$ century. Evidences suggest that globally, there have been more flood/drought-inducing events, which are set to escalate in frequency and intensity in the future (Sarah, 2002; Tebaldi et al., 2006). The average temperature rise in Africa is faster than the global average and is likely to persist in the future. This warming occurred at the rate of about $0.5^{\circ} \mathrm{C}$ per decade with a slightly larger warming in

${ }^{\star}$ Corresponding author. E-mail: t.g.gidey@utwente.nl. Tel: +31 (0)53 4874 273. Fax: +31 (0)53 4874575. crops are grown close to the thermal tolerance limits (Collier et al., 2008).

The Third Assessment Report of the International Panel on Climate Change (IPCC) indicated that developing countries are expected to suffer most from the negative impacts of climate change and climate variability (IPCC, 2001) ${ }^{1}$. This is due to the economic importance of climate- sensitive sectors for these countries and to their limited human, institutional and financial capacity to anticipate and respond to the direct and indirect effects of climate change and variability. This is particularly true in Africa where there is high direct dependence on the

${ }^{1}$ Climate variability refers to variations in the mean state and other climate statistics (such as standard deviations, the occurrence of extremes, etc.) on all temporal and spatial scales beyond those of individual weather events. Variability may result from natural internal processes within the climate system (internal variability) or from variations in natural or anthropogenic external forces (external variability) (IPCC, 2007a). 
natural environment for livelihood and high levels of poverty (Alexandrov and Hoogenboom, 2000; Dixon et al., 2001). Particularly, Africa's agriculture is negatively affected by climate change and climate variability (Conway and Schipper, 2011). In most developing countries and in many African countries, agricultural production including access to food is projected to be severely compromised by climate change and variability (IPCC, 2007a).

Hellmuth et al. (2007) reported that alterations in the patterns of extreme events, setback the development process of African countries for decades and threaten the lives and livelihoods of the poor more than other social groups. Occurrence of a single climate disaster is capable of stagnating or even-reversing the economic growth achieved over a decade as the main source of economic growth of African countries are climate-related sectors. This is attributed to the fact that climate change and variability is expected to affect the two most important direct agricultural production inputs: precipitation and temperature. These inputs are crucial for livelihoods in Africa, where majority of the population relies on local supply systems sensitive to climate variation (Watson et al., 1998; IPCC, 2001; Deschênes and Greenstone, 2007). As the adverse impacts become more frequent and severe, the already fragile socioeconomic activity of the continent is more likely to exacerbate (McCarthy et al., 2001; Adger et al., 2003; Collier et al., 2008).

Like other African countries, Ethiopia is widely held to be highly vulnerable to future climate change (Conway and Schipper, 2011). In Ethiopia, drought remains the country's major hazard, with floods following in second place. Recurrent droughts form the major threat to rural livelihoods and food security in the country. A marked increase in both size and frequency has recently become apparent (Ferris-Morris, 2003). Funk et al. (2005) reported that rainfall in Ethiopia is expected to decline in the future and also become more irregular. A recent study by UNDP (2008) also indicates that climate change in Ethiopia could lead to extreme temperatures and rainfall events, as well as more heavy and extended droughts and floods. Accordingly, considering the fact that the country is highly dependent on the agricultural sector for income and food security, erratic monsoon precipitation would adversely affect the lives perhaps the majority of the populations (Haile, 2005). Dercon (2004) reported that in Ethiopia, a season with starkly reduced rainfall depressed consumption even after four to five years.

Furthermore, the country's agro-ecosystem is also highly sensitive to rainfall and has low adaptive capacity to respond to damages. As a result, a slight change in climate will have a large impact on the socio-economic activity of the country (Fraser, 2007). Despite agriculture being given an overriding emphasis as a core sector to bring future sustainability to the country, the sector is recently challenged by climate change and variability. Climate change and associated risks are therefore expected to have serious consequences for the country's economy, and agriculture and food security in particular.

With global warming being a reality (Datsenko and Sonechkon, 1999; Peterson et al., 1999; Easterling et al., 2000), it is important to be informed and regularly updated on observed regional precipitation and temperature trends. However, despite the intensity and frequency of climate hazard is increasing in the study area, studies that scientifically assess the long term fluctuations in climate parameters are seriously lacking. As a result, documented information regarding to what extent do significant climate parameters vary over the past decades is scanty. Therefore, empirical studies that examine the change in climate parameters in the study area are pertinent.

The main objectives of this work is to statistically investigate the temporal change in the significant climate parameters and identify drought periods in Tigray, Ethiopia. Precipitation and temperature are the main parameters analysed. A combination of different approaches was employed for this study. The prevalence of meteorological drought and climate variability was assessed using standardized rainfall anomaly and conventional method of classifying meteorological drought based on the Ethiopian National Meteorological Services Agency (ENMSA) definition. We applied spatial autocorrelation analysis to capture the spatial clustering of drought occurrence across the study area. We believe that this study will guide policymakers regarding contingency planning to be employed for agriculture and water supply in the face of anticipated changes in climate. The rest of the paper is structured as follows: Section 2 describes the geographic setting of the study area, the datasets, and the analytical tools employed in this research. Results are presented in section 3 and section 4 concludes with policy implications.

\section{MATERIALS AND METHODS}

\section{Geographic setting of the study area}

Tigray is one of the regional states of Ethiopia located in the north part of the country, covering a total area of 53,000 square kilometres (Figure 1). Geographically, it lies between latitudes $12^{\circ} 15^{\prime} \mathrm{N}$ and longitudes $14^{\circ} 57^{\prime} \mathrm{N}$, and 36일 is structured into six administrative zones and 34 rural districts (locally called woreda-the second administrative level below the zone). The total population surpasses 4.3 million, about $82 \%$ of whom live in rural areas (CSA, 2008).

Climatically, the region belongs to the sub-tropics and monsoon weather prevails throughout the year. In general, three distinct seasons can be recognized in Tigray. The first is the main rainy monsoon season which lasts from June to September (locally called Kiremti), the second is the dry winter season from October to February, and the third is pre-monsoon hot season from March to May. The regional climate is characterized by large spatial and temporal variations and frequent drought. Like the rest of Ethiopia, the economy of Tigary is agriculture based. The tremendous importance of this sector to the regional economy can be gauged 


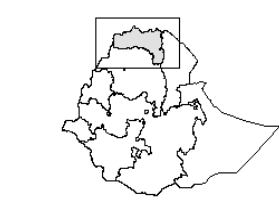

Legend

Zone boundary

Woreda boundary
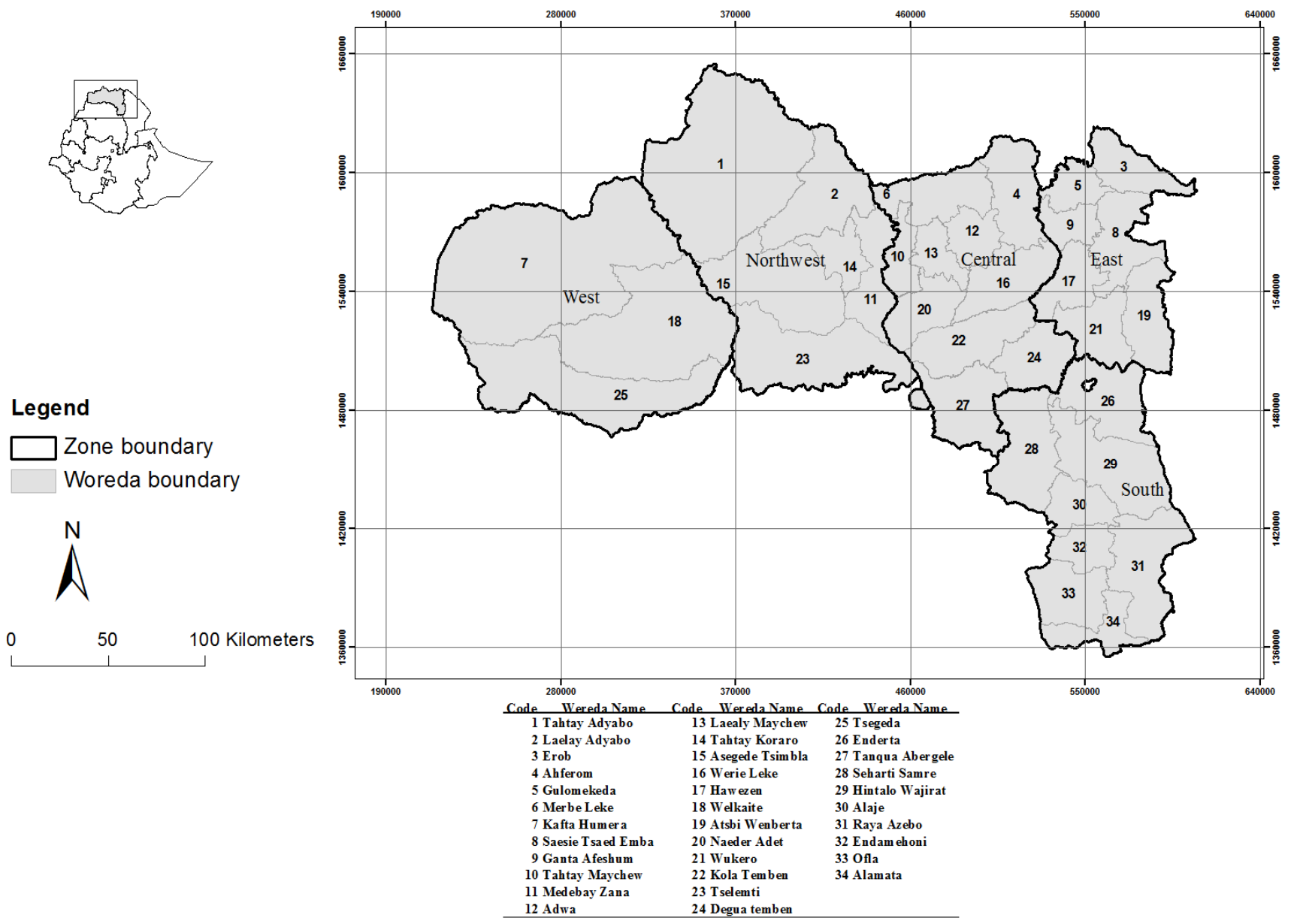

Figure 1. Administrative map of Tigray region, Ethiopia.

by the fact that it directly supports about $80 \%$ of the population in terms of employment and livelihood (CSA, 2008). Agricultural systems are rain-fed and dominated by small-scale farmers with an average land holding of less than one hectare per family. In addition, the agricultural sector is highly susceptible to climate variability, seasonal shifts in rainfall, resulting in drought. Major parts of northern Ethiopia experience year-round water deficit. Drought is frequent due to abnormally low and untimely rainfall. Even commencement of rainfall at the right time cannot guarantee a drought-free season since frequency, intensity; amount and duration of rainfall all play crucial roles in the occurrence of drought. Tigray is dry for most of the year except during the rainy season, and exhibits a semi-arid climate. Almost every year, the study area experiences localized droughts causing crop failure and jeopardizing development activities. Recurrent droughts form the major threat to rural livelihoods and food security in the study area. The situation is worsened by the fact that majority of these farmers are so poor that they have no assets at their disposal (van der Veen and Tagel, 2011). As such, agricultural shocks are important source of vulnerability for the majority of the populations.

\section{Data used}

Historical records of monthly rainfall and temperature data from 46 in-situ stations for the period 1954-2008 were provided by the ENMSA. However, the period of records for these stations varies and some have missing records. Thus, the period of study has been chosen as long as possible depending on the availability of recorded data. Relatively long rainfall records were obtained for 25 in-situ stations with a reasonably good geographic distribution to cover the study area. In addition, data on the incidence of drought for the period 1970-2008 and annual crop production for the period 1992-2008 were acquired from Federal Disaster Prevention and Preparedness Commission, and Tigray Region Bureau of Finance and Economic Development (BOFED), respectively.

\section{Method}

A drought may be defined as a deficit of water in time and space. However, there is no general view among researchers towards a comprehensive parameterization of a drought event unfortunately due to the complex nature of the phenomenon. Several definitions of drought can be found depending on the specific way it is measured. Generally, droughts can be classified into meteorological droughts, agricultural droughts, and hydrological droughts (Dracup et al., 1980; Wilhite and Glantz, 1985). In this paper, drought is considered to be a meteorological phenomenon characterized by prolonged period of abnormal precipitation deficit. Different indices are used for the identification of drought (Tate and Gustard, 2000; Keyantash and Dracup, 2002). The most commonly used meteorological drought indices are: (1) Discrete and cumulative precipitation anomalies, (2) Standardized Rainfall Anomalies (Jones 
Table 1. Selected weather stations and their geographic information.

\begin{tabular}{|c|c|c|c|}
\hline Weather stations & $\begin{array}{c}\text { Latitude } \\
\text { (North) }\end{array}$ & $\begin{array}{c}\text { Longitude } \\
\text { (East) }\end{array}$ & $\begin{array}{c}\text { Altitude } \\
\text { (m) }\end{array}$ \\
\hline Adigudom & $13^{\circ} 15^{\prime}$ & $39^{\circ} 31^{\prime}$ & 2100 \\
\hline Adigrat & $14^{\circ} 16^{\prime}$ & $39^{\circ} 26.86^{\prime}$ & 2497 \\
\hline Adwa & $14^{\circ} 11^{\prime}$ & 38 `53’ & 1911 \\
\hline Axum & $14^{\circ} 07^{\prime}$ & $38^{\circ} 44^{\prime}$ & 2105 \\
\hline Aynalem & $13^{\circ} 28^{\prime}$ & $39^{\circ} 29^{\prime}$ & 2195 \\
\hline Dengolat & $13^{\circ} 19^{\prime}$ & $39 \circ 19^{\prime}$ & 2070 \\
\hline Edgahamus & $14^{\circ} 11^{\prime}$ & $39^{\circ} 33.19^{\prime}$ & 2708 \\
\hline Hagreselam & $13^{\circ} 38.77$ & $39^{\circ} 10.476^{\prime}$ & 2618 \\
\hline Hawzen & $13^{\circ} 58^{\prime}$ & $39^{\circ} 25^{\prime}$ & 2242 \\
\hline Abey- Adi & $13^{\circ} 36^{\prime}$ & $39^{\circ} 00^{\prime}$ & 1829 \\
\hline Maichew & $12^{\circ} 47^{\prime}$ & 39 `32’ & 2432 \\
\hline Maykental & $13^{\circ} 56^{\prime}$ & $38^{\circ} 59^{\prime}$ & 1845 \\
\hline Mekele & $13^{\circ} 28^{\prime}$ & $399^{\circ} 1^{\prime}$ & 2257 \\
\hline Selekeleka & $14^{\circ} 06^{\prime}$ & $38^{\circ} 20^{\prime}$ & 1975 \\
\hline Shire & $14^{\circ} 06^{\prime}$ & $38^{\circ} 18^{\prime}$ & 1897 \\
\hline Wukero & $13^{\circ} 47^{\prime}$ & $39^{\circ} 36^{\prime}$ & 1977 \\
\hline
\end{tabular}

and Hulme, 1996), (3) the Palmer Drought Severity Index (PDSI) (Palmer, 1965), (4) the Rainfall Anomaly Index (RAI) (van Rooy, 1965), and (5) the Standardized Precipitation Index (SPI) (McKee et al., 1993).

In this study, we used the standardized rainfall anomaly to examine the temporal characteristics of climate variability and determine the prevalence droughts over the period 1954-2008. Rainfall anomaly was computed as:

$R F A_{i}=\left(\frac{R F_{i}-R F_{\mu}}{R F_{\mu}}\right) * 100$

where, ${ }_{R F A_{i}}$ is rainfall anomaly for $i^{\text {th }}$ year; $R F_{i}$ is annual rainfall for $i^{t h}$ year and $R F_{\mu}$ is long-term mean annual rainfall. Subsequently, inter-annual annual rainfall variability was determined by the coefficient of variation (CV), which is obtained by dividing the standard deviation of the annual rainfall by the average long-term rainfall over the given period. Similar method was applied to determine inter-annual variability of monthly minimum and maximum temperature. Besides, the Kiremti ('main rains', June September) rainfall and temperature of each station have been spatially interpolated using ordinary kriging technique with a spherical semi-variogram model in a software package Integrated Land and Water Information System (ILWIS) to create long-term seasonal rainfall and temperature maps for the study area.

Drought per se is a very diffuse concept and the threshold identified for defining it is set somewhat arbitrarily (Wilhite, 2000). Meteorological drought, a statistical measurement of negative rainfall anomaly, is normally defined in terms of some percentage reduction from the average annual or seasonal rainfall. It differs for each country and purpose chosen (Heim, 2000; Wilhite, 2000). In Ethiopia, the ENMSA defines 50 to $75 \%$ deviation of a 30 year average as 'below-normal' rainfall for dry season and 0 to $50 \%$ deviation of average rainfall as 'much-below-normal' rainfall for the very dry years. Accordingly, this conventional method of classifying meteorological drought was also used as a second alternative to examine rainfall variability in the study area.

Furthermore, rainfall characteristics such as variations in maximum, minimum and mean rainfall; and variations in annual and seasonal rainfall were analysed based on eighteen years of daily rainfall (1991-2008) from sixteen ground based in-situ rainfall stations, which are assumed to represent the region. This was performed using a classic statistical tool called analysis of variance (ANOVA). The purpose of ANOVA is to test the null hypothesis that rainfall characteristics does not vary significantly between the sixteen rain gauge stations. Based on Steel and Torrie (1981), a test statistic called ' $F$ ' tests at $5 \%$ level of significance was employed to test the equality of means and variances of rainfall data across the rain gauge stations. Generalised geographic information of the selected weather stations used for examining rainfall characteristics is illustrated in Table 1.

To capture the spatial clustering of drought occurrence across the study area, we applied spatial autocorrelation analysis. A spatial autocorrelation indicator, Moran's Index, was performed in GeoDa software to capture the global spatial autocorrelation and local spatial clustering of drought events. Spatial autocorrelation statistics has been widely used to measure the correlation among neighbouring observations in a pattern and the levels of spatial clustering among neighbouring districts (Boots and Getis, 1998). The Moran's I test statistic is given by:

$I_{M}=\left(\frac{n}{\sum_{i} \sum_{j} W_{i j}}\right) \frac{\sum_{i} \sum_{j} W_{i j}\left(Y_{(R) i}-\bar{Y}_{(R)}\right)\left(Y_{(R) j}-\bar{Y}_{(R)}\right)}{\sum_{i}\left(Y_{(R) i}-\bar{Y}_{(R)}\right)^{2}}$

Where, $W_{i j}$ is the element in the spatial weights matrix corresponding to the district pairs $i, j$; and $Y_{(R) i}$ and $Y_{(R) j}$ are the frequency of drought for districts $i$ and $j$ with mean drought frequency of $\bar{Y}_{(R)}$. Since the weights are not row-standardized, the scaling factor $/ \sum_{i}^{n} \sum_{j} W_{i j}$ is applied. Moran's Index (I) indicates the strength of the spatial clustering among neighbouring districts. A positive Moran's I indicates the presence and degree of spatial 


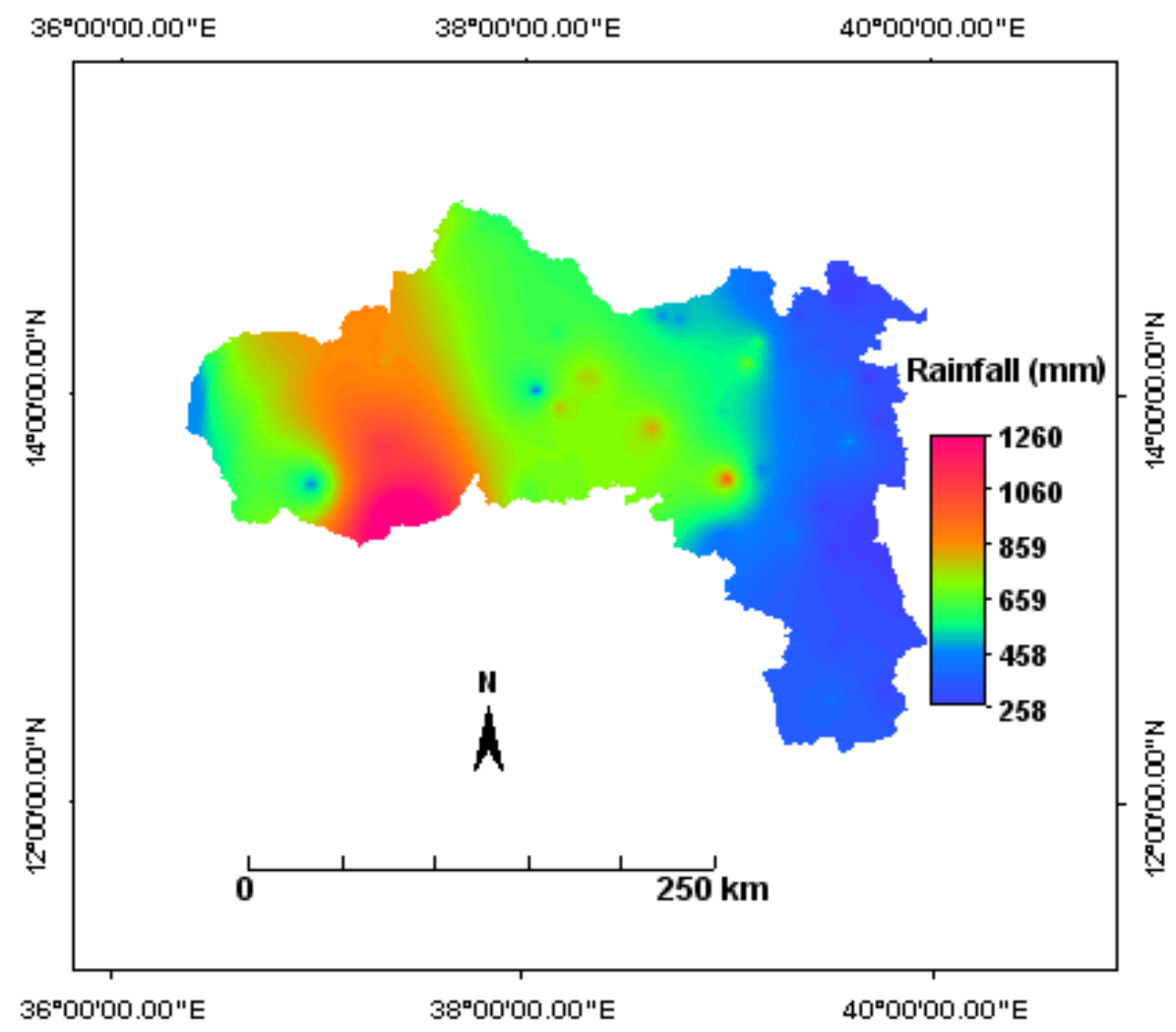

Figure 2. Spatial distribution of long-term average kiremti rainfall in Tigray.

autocorrelation. The first step in the analysis of spatial autocorrelation is to construct a spatial weights matrix that contains information on the neighbourhood structure over the entire study area, $W_{i j}$. The weight matrix was constructed using a first order rook connectivity weight matrix based on the districts who share common boundary.

$W_{i j}=\left\{\begin{array}{lcc}1 & \text { if districts } & \mathrm{i} \text { and } \mathrm{j} \text { share common boundary } \\ 0 & \text { otherwise }\end{array}\right.$

A significance test against the null hypothesis of no spatial autocorrelation was also carried out. Finally, relationships between crop production and rainfall anomalies over the entire crop growing period were analysed using Pearson correlation coefficients based on 17 years grain data. This was obtained by dividing the covariance of the two variables by the product of their standard deviations. As Parry et al. (2004) described it, this exploratory analysis serves to identify those variables that explained a significant proportion of the observed yield variance.

\section{RESULTS}

\section{Change in significant climate parameters}

\section{Rainfall variability and trend}

Rainfall, which is the main climatic factor, is distributed very unevenly in the study area. The climate is characterized by large spatial variations which range from about 1000-1260 mm year ${ }^{-1}$ in some pockets areas in the
Southwest to about less than $300 \mathrm{~mm} \mathrm{yr}-1$ in the Northeast lowlands (Figure 2). Estimates from the historical records of precipitation for the period 19542008 indicate that the mean annual rainfall is $560.7 \mathrm{~mm}$ while the mean annual kiremti rainfall is $473 \mathrm{~mm}, 84 \%$ of the annual rainfall. Most areas receive less than $400 \mathrm{~mm}$ of rainfall yearly indicating the existence of spatial variations in precipitation consistent with topographic difference. During the Kiremti rainy season (June September), the southern and eastern parts of the study area receive low rainfall as compared to the other zones. Figure 2 clearly displays an increasing rainfall pattern from the southern part to the western part of Tigray. Meteorological drought indicates the deficiency of rainfall compared to normal rainfall in a given region. The major impact of drought is felt in semi-arid regions where the incidence of drought years is fairly high. Within this context the temporal fluctuations of annual rainfall in the study area were analysed in terms of the normalized rainfall anomaly. The temporal analysis indicated that rainfall pattern in the study area exhibited a very high variability over time and is quite often accentuated with positive and negative anomalies (Figure 3). Consequently, years like 1960, 1961, 1962, 1964, 1965, 1966, 1971, 1982, 1983, 1984, 1985, 1987, 1991, 1994, 2000, 2002, 2003 and 2004 can be described as meteorological drought years in statistical terms, where a period of negative rainfall anomalies in respect to the 


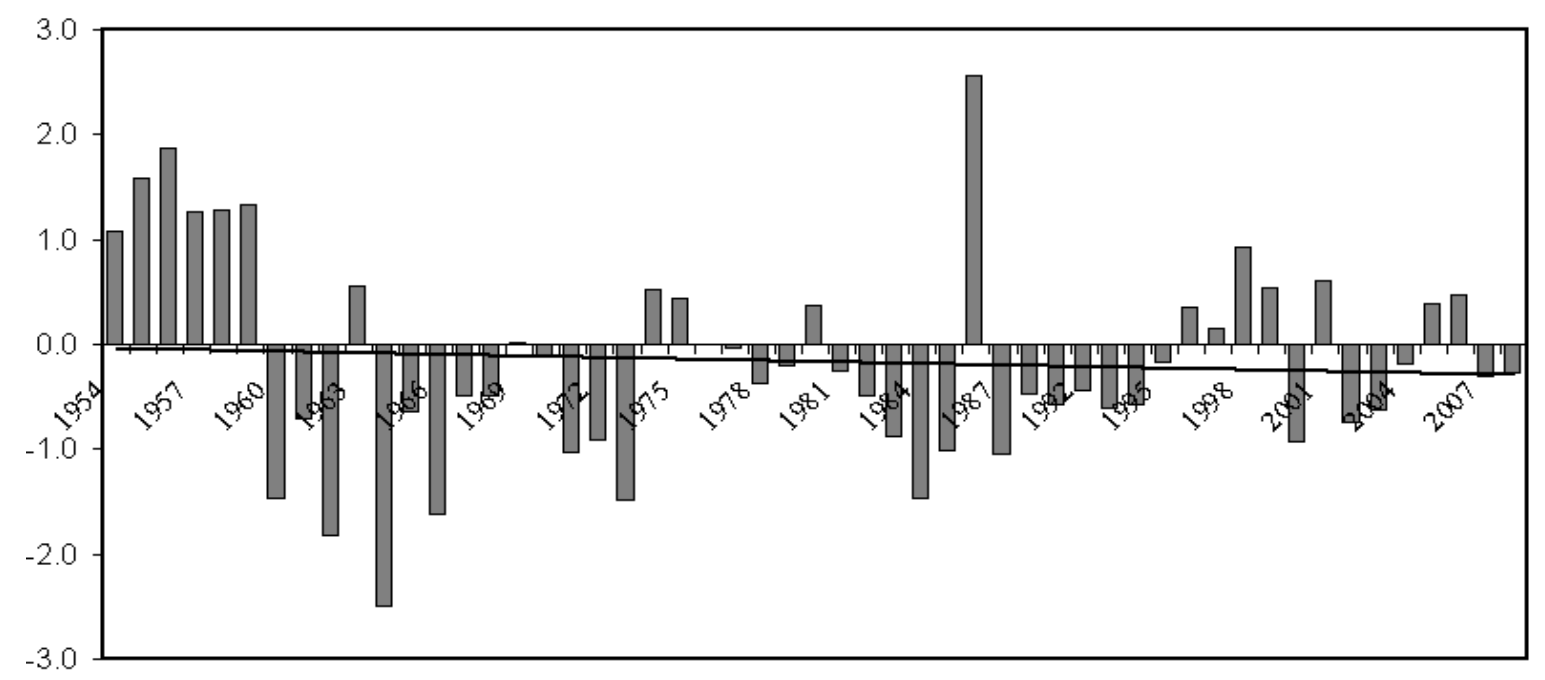

Figure 3. Long-termannual rainfall anomalies of Tigray (1954-2008).

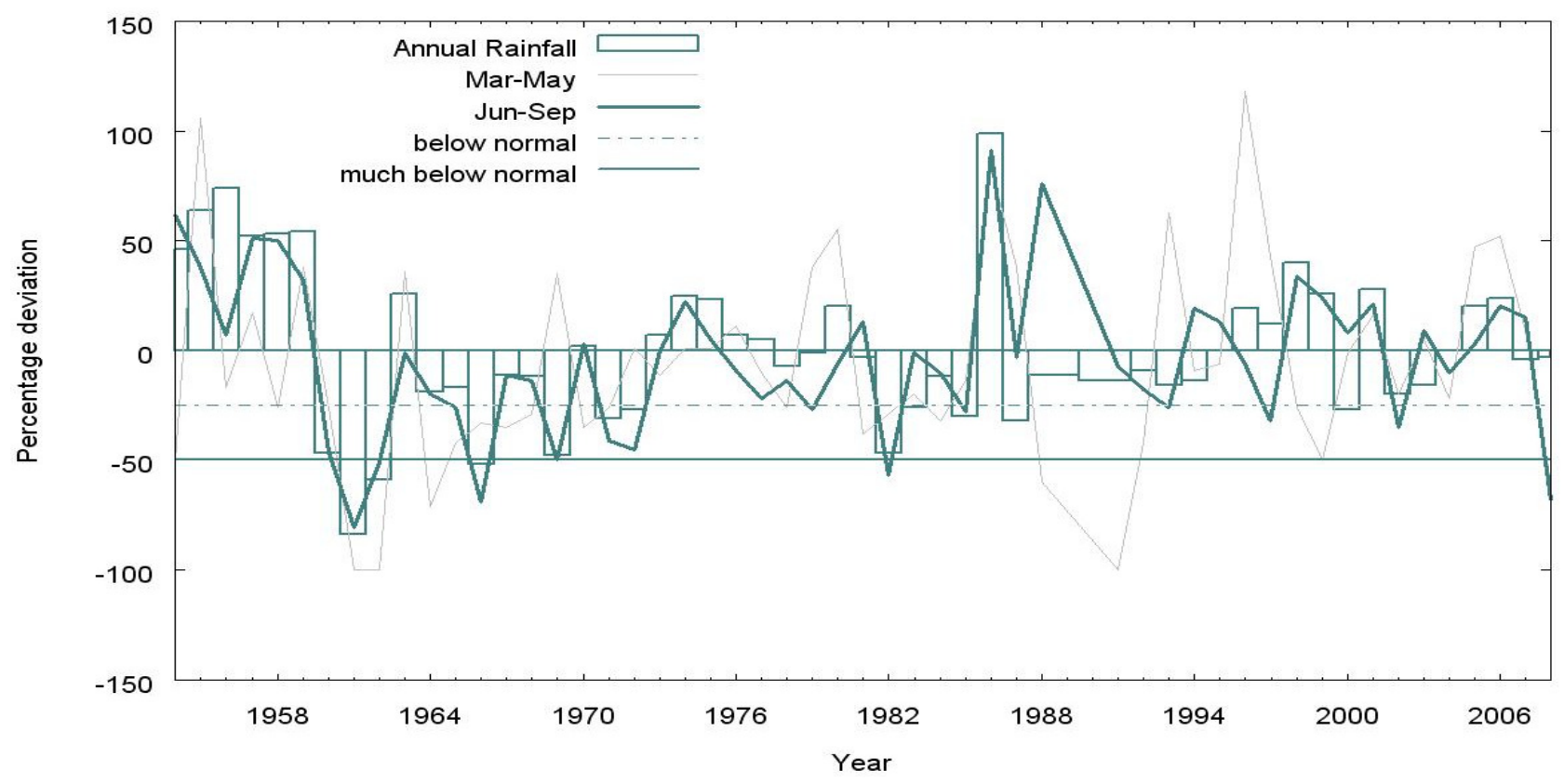

Figure 4. Departure of seasonal rainfall based on the 1977-2008 mean. The ENMSA definitions of dry and very dry years, the below-normal line (-25\% line) and much-below-normal line (-50\%) are shown.

long-term mean is viewed as drought condition. In contrast, 1954, 1955, 1956, 1958, 1959, 1963, 1974, 1986, 1996, 1998, 1999, 2001, and 2006 were normal years.

Moreover, historical records of precipitation in the study area was analysed based on the definition of ENMSA. It is apparent that the deviations of long-term annual and Kiremti (June-September) precipitation from their longterm average were very low in the first half of the time series (Figure 4). While deviations in this period were dominantly negative, accentuated kiremti precipitation marked by high negative deviation was noted in 1964, with values $82 \%$ lower than the corresponding long-term average ever recorded for the study area. Pronounced departures were also noted in the period between 1984 and 1985, with deviations from the long-term average reaching up to $47 \%$ lower than the long-term average observed in 1984 for annual rainfall and $56 \%$ observed in the same period kiremti rainfall. This period was succeeded by years of consecutively diminishing rainfall 
Table 2. Annual and seasonal rainfall data $(\mathrm{mm})$ and associated CV for the period 1991-2008, from sixteen rain gauge stations in Tigray.

\begin{tabular}{|c|c|c|c|c|c|c|c|c|c|c|c|c|c|c|c|c|c|}
\hline \multirow{2}{*}{ Rainfall } & \multirow{2}{*}{ Property } & \multicolumn{16}{|c|}{ Stations } \\
\hline & & Adigudom & Adigrat & E.hamus & Adwa & Axum & Aynalem & Dengolat & Hagreselam & Hawzen & Maichew & Maykental & Mekele & Selekeleka & Shire & Wukero & Mean \\
\hline \multirow{4}{*}{$\begin{array}{l}\text { Annual } \\
\text { Rainfall }\end{array}$} & Min & 241 & 313 & 110 & 218 & 360 & 278 & 517 & 449 & 275 & 427 & 366 & 326 & 310 & 710 & 162 & 368 \\
\hline & Max & 1104 & 770 & 819 & 1054 & 1037 & 814 & 820 & 900 & 886 & 1262 & 797 & 755 & 1548 & 1214 & 1040 & 1095 \\
\hline & Mean & 498 & 600 & 469 & 742 & 712 & 529 & 669 & 683 & 522 & 750 & 629 & 583 & 960 & 960 & 564 & 709 \\
\hline & CV & 0.42 & 0.22 & 0.34 & 0.29 & 0.28 & 0.26 & 0.15 & 0.19 & 0.30 & 0.28 & 0.17 & 0.21 & 0.36 & 0.15 & 0.45 & 0.28 \\
\hline \multirow{5}{*}{$\begin{array}{l}\text { Long } \\
\text { rains }\end{array}$} & Min & 212 & 239 & 171 & 75 & 159 & 203 & 400 & 368 & 223 & 220 & 298 & 289 & 218 & 582 & 48 & 267 \\
\hline & Max & 1061 & 608 & 636 & 973 & 937 & 792 & 743 & 795 & 734 & 677 & 648 & 688 & 1396 & 1004 & 950 & 950 \\
\hline & Mean & 441 & 367 & 324 & 616 & 557 & 431 & 549 & 552 & 409 & 454 & 518 & 472 & 815 & 790 & 478 & 564 \\
\hline & CV & 0.48 & 0.27 & 0.40 & 0.37 & 0.42 & 0.33 & 0.20 & 0.22 & 0.36 & 0.27 & 0.19 & 0.25 & 0.39 & 0.15 & 0.49 & 0.34 \\
\hline & $\%$ Ann. mean & 89 & 61 & 69 & 83 & 78 & 82 & 82 & 81 & 78 & 61 & 82 & 81 & 85 & 82 & 85 & 79 \\
\hline \multirow{5}{*}{$\begin{array}{l}\text { Short } \\
\text { rains }\end{array}$} & Min & 2 & 37 & 0 & 22 & 23 & 26 & 18 & 29 & 18 & 39 & 4 & 11 & 3 & 25 & 12 & 18 \\
\hline & Max & 114 & 394 & 258 & 270 & 276 & 218 & 277 & 169 & 171 & 412 & 271 & 274 & 299 & 240 & 249 & 264 \\
\hline & Mean & 50 & 159 & 106 & 92 & 95 & 85 & 100 & 98 & 80 & 171 & 75 & 86 & 98 & 88 & 77 & 97 \\
\hline & CV & 0.66 & 0.58 & 0.67 & 0.68 & 0.79 & 0.73 & 0.68 & 0.49 & 0.64 & 0.60 & 0.89 & 0.78 & 0.91 & 0.58 & 0.95 & 0.74 \\
\hline & $\%$ Ann. Mean & 10 & 27 & 23 & 12 & 13 & 16 & 15 & 14 & 15 & 23 & 12 & 15 & 10 & 9 & 14 & 14 \\
\hline
\end{tabular}

$\%$ Ann., percent of annual.

variability which persisted until 1993.

\section{Rainfall characteristics based on rainfall gauges}

Rainfall characteristics such as variations in annual and seasonal rainfall were analysed using a classic statistical tool called ANOVA. The result showed that the mean annual rainfall, based on 18 years rainfall record, of the sixteen rainfall recording stations was $709 \mathrm{~mm}$ with a station rainfall range from $469 \mathrm{~mm}$ (Edagahamus station) to $960 \mathrm{~mm}$ (Selekeleka station). During the eighteen years of rainfall record, mean annual rainfall amounts were below the mean in seven years. The coefficients of variation (CV) of station rainfall ranged between 15 and $45 \%$ indicating that the variability in rainfall amounts between the rainfall stations is high (Table 2 ). The seasonal rainfall analysis further indicates that long rains (June - September) bring about $564 \mathrm{~mm}$ (79\%) and the short rains (March - April) bring about 97 $\mathrm{mm}(14 \%)$ of the total annual rainfall. Hence about $93 \%$ of the total annual rainfall occurs in the two rainy seasons. Analysis of rainfall data for the selected rainfall gauge further indicate that the mean $\mathrm{CV}$ of the long rainfall season is found to be 0.34 , which is smaller than that of the short rainfall season, $C V=0.74$.

The coefficient of variation (CV) of annual and long rains across the study area is spatially shown in Figure 5, in which one can distinguish that the southern part is a singular area of Tigray, presenting coefficients of variation of kiremti precipitation (long rains) much higher than the rest part of Tigray. One-way ANOVA was further carried out to test if the rainfall at the stations belongs to the same population. It is thus first hypothesised that there is no significant difference in annual rainfall and seasonal rainfall across the selected rainfall stations. This analysis was carried out using the ' $F$ ' test. The finding indicates that the observed significance value for annual and seasonal rainfall is less than 0.01 implying that there is a significant difference in annual and seasonal rainfall between the sixteen meteorological stations, confirming the existence of spatial variations across stations in the study area (Table 3).

\section{Spatial clustering of drought occurrence}

Drought is one of the utmost important disasters associated with climate variability, which cause instability in food production in the study area. Data on the incidence of drought reveals that the frequency and spatial distribution of drought have increased over the period 1970-2008. The spatial 


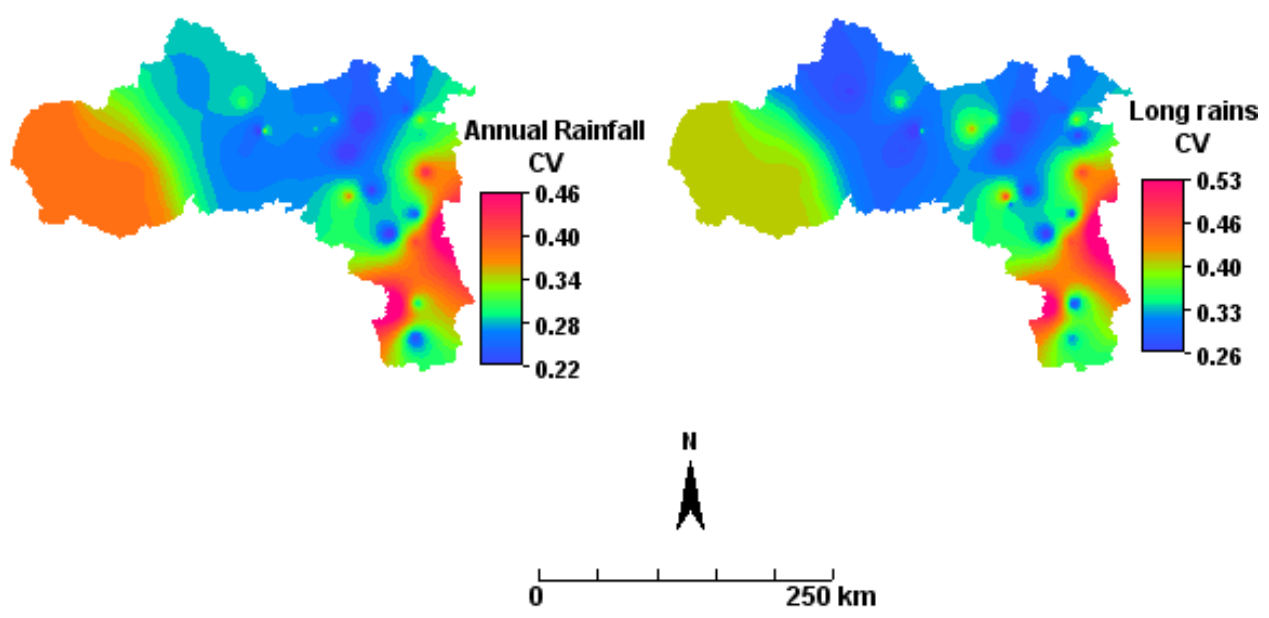

Figure 5. Spatial distribution of coefficient of variation for annual and kiremti rainfall, long rains, (June - September).

Table 3. ANOVA results for rainfall between sixteen rainfall stations.

\begin{tabular}{|c|c|c|c|c|c|}
\hline Season & $\begin{array}{l}\text { Source of } \\
\text { variation }\end{array}$ & $\begin{array}{c}\text { Sum of } \\
\text { squares }\end{array}$ & $\begin{array}{c}\text { Mean } \\
\text { square }\end{array}$ & $F_{\text {cal }}$ & Sig. \\
\hline Annual rainfall & $\begin{array}{l}\text { Between groups } \\
\text { Within groups }\end{array}$ & $\begin{array}{l}5072346.4 \\
8061223.9\end{array}$ & $\begin{array}{c}362310.5 \\
33728.9\end{array}$ & 10.7 & 0.000 \\
\hline Long rains & $\begin{array}{l}\text { Between groups } \\
\text { Within groups }\end{array}$ & $\begin{array}{l}4352392.2 \\
7101643.9\end{array}$ & $\begin{array}{c}310885.2 \\
29713.9\end{array}$ & 10.5 & 0.000 \\
\hline Short rains & $\begin{array}{l}\text { Between groups } \\
\text { Within groups }\end{array}$ & $\begin{array}{c}225326.2 \\
1142177.3\end{array}$ & $\begin{array}{c}16094.7 \\
4778.9\end{array}$ & 3.4 & 0.000 \\
\hline
\end{tabular}

analysis of drought frequency provides evidence that most of the drought events have been geographically concentrated in the eastern and southern parts of Tigray, with some of the districts experiencing high frequency of droughts (Figure 6).

The extent to which drought frequency of occurrence in the neighbouring districts are correlated was measured using the Moran's Index. A Moran's Index analysis is conducted by generating scatter plots with the drought frequency variable. In essence, the scatter plots illustrate the Global Moran's I (Figure 7), which is a commonly used test statistic for spatial autocorrelation. A significance assessment through a permutation procedure was implemented to determine the significance of the computed Moran's Index. Moran's Index is found to be positive and statistically significant ( $p$ $<0.05$ ) as it is shown in Table 4.

\section{Temperature variability and trend}

At the root of climate, is global warming. The warming occurs worldwide and temperature is rising on the African land mass and the surrounding oceans. Some studies have indicated that warming has occurred across much of Ethiopia, particularly since the 1970s, at a variable rate (Conway et al., 2004; IPCC, 2007b). A study made by ENMSA also reveals that there has been a warming trend in temperature over the past 50 years in the country. The average annual minimum temperature over the country has been increasing by about $0.25^{\circ} \mathrm{C}$ every ten years while average annual maximum temperature has been increasing by about $0.10^{\circ} \mathrm{C}$ every decade (ENMSA, 2001). Against this backdrop, the inter-annual variability of annual minimum and maximum temperature distribution in study area was analysed.

The study area experiences mild temperature for its tropical latitude because of its topography. Mean annual temperature distribution in the study area varies from about $13.4^{\circ} \mathrm{C}$ over the high lands of southwest, and East to about $28^{\circ} \mathrm{C}$ over Western lowlands for the year 2008 (Figure 8). The spatial distribution of temperature shows an increasing minimum and maximum temperature pattern from southern to the western parts of the region.

The analysis on the inter-annual variability of monthly average minimum and maximum temperature showed 


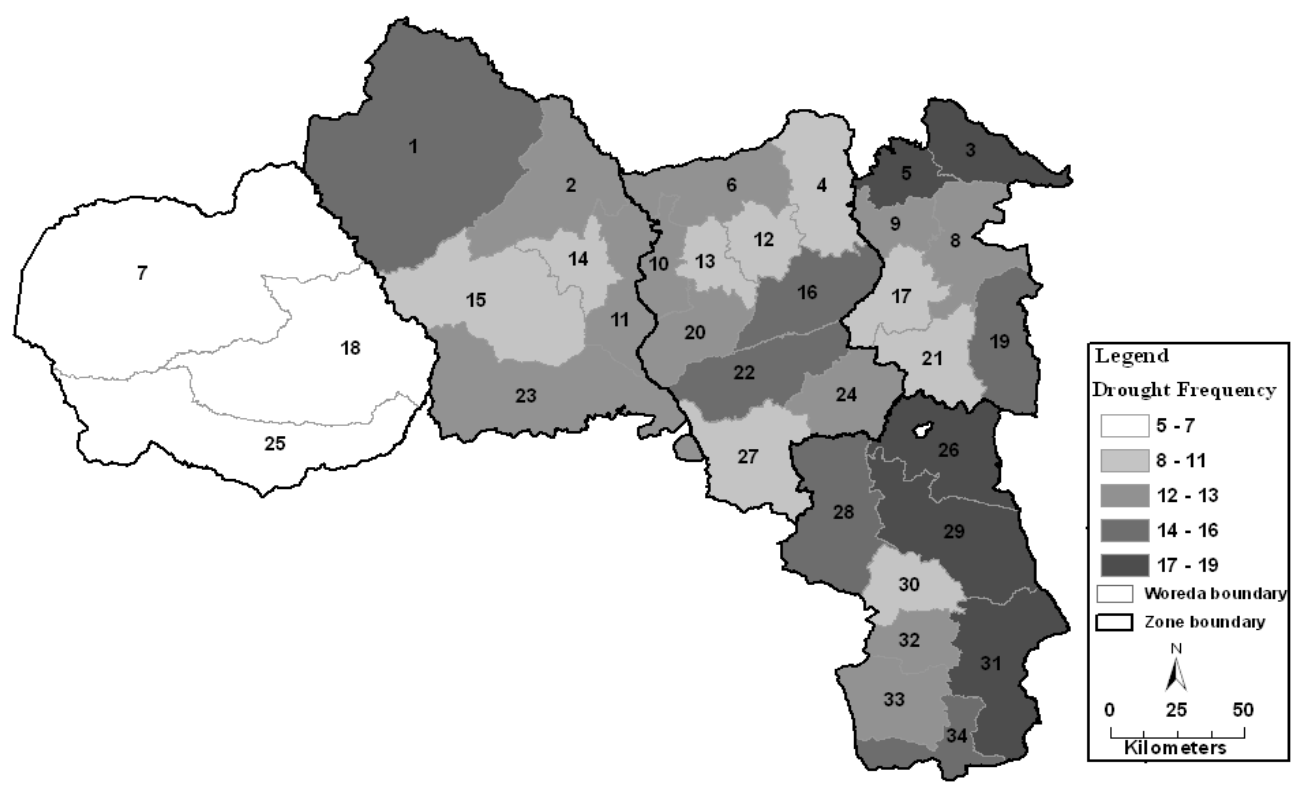

Figure 6. Spatial distribution of drought frequency in Tigray region for the period 1970-2008 (Refer Figure 1 for the numbers).

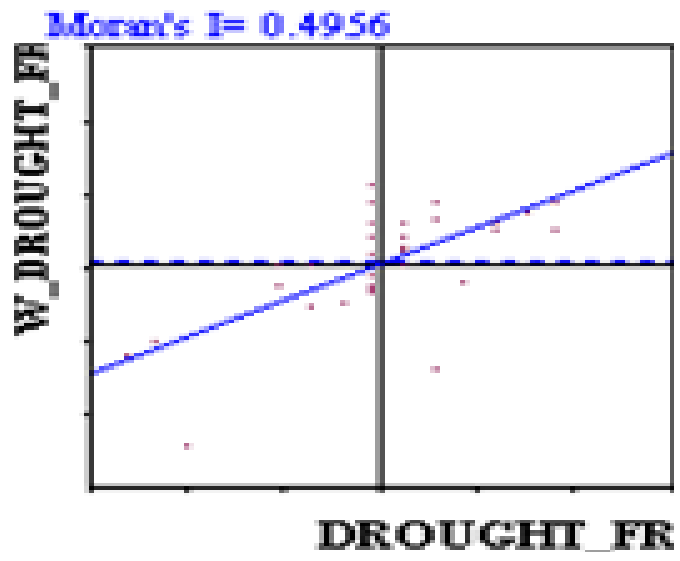

Figure 7. Scatter plot for drought frequency.

that minimum temperature is highest in May and reaches its lowest value in December (Figure 9). The mean of the minimum temperature is $11.6^{\circ} \mathrm{C}$. The temporal pattern of the maximum temperature is different to that of the minimum temperature with their lowest value occurring in August. The maximum temperature in the study area is highest in May and reaches its lowest in August. The mean of the maximum temperature is $26.1^{\circ} \mathrm{C}$.

The year to year variation of annual minimum and maximum temperatures is further examined in terms of standardized temperature anomalies. The temporal analysis indicates that temperature in Tigray has significantly increased over the period 1954-2008. The study area has experienced both warm and cool years over the period. Years like 1957, 1958, 1973, 1987 and
1995 were very warm while 1964, 1967, 1968, 1975, 1977 and 1989 were very cool years (Figures 10 and 11).

\section{Crop production and weather fluctuations}

Global climate change is expected to affect all economic sectors to some degree, but the agricultural sector is perhaps the most sensitive and vulnerable. World agriculture, whether in developing or developed countries, remains very dependent on climate resources (Downing, 1996; Watson et al., 1996). Crop production yields are affected by variations in climatic factors such as rising temperature and changing precipitation regimes, and the frequency and severity of extreme events like droughts, floods, and hailstorm (Alexandrov and Hoogenboom, 2000; Collier et al., 2008; Conway, 2008). Like other developing countries' economies, especially in Sub-Saharan Africa (SSA), agriculture forms the basis of the economy in Ethiopia supporting roughly $42 \%$ GDP and $80 \%$ employment (Byerlee et al., 2007). Ethiopia's economy is highly exposed to climate variability and extremes. The agricultural sector is almost totally dependent on rainfall with irrigation covers only less than $5 \%$ of agricultural crop areas (Diao, 2010). Most of the crops are grown in the longer rainy season, Kiremti, and Ethiopian agriculture largely depends on this rain, which is characterized by high spatial variation (Block and Rajagopalan, 2007). Generally, in Ethiopia, precipitation deficit is the main that limit growth, development, and final yield of crop production; and that induces food shortages. For example, Webb (1992) reported that a $10 \%$ decrease in the amount of rainfall below the 
Table 4. A summary result for Moran's I test statistics.

\begin{tabular}{ccc}
\hline Moran I statistics & Expectation & Variance \\
\hline 0.496 & -0.0303 & 0.010696 \\
\hline
\end{tabular}

Moran I statistic standard deviate $=3.0009$. $p$-value $=0.00135$. Alternative hypothesis: greater.
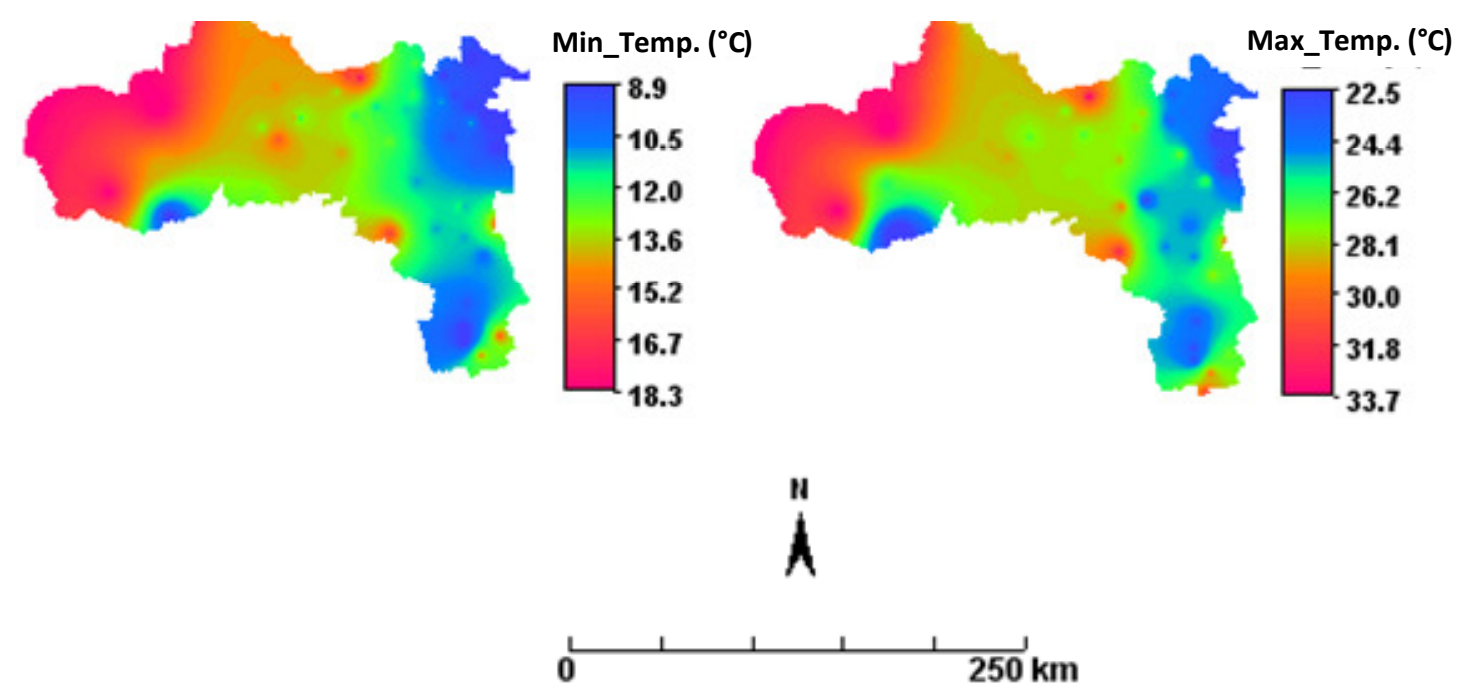

Figure 8. Spatial distribution of mean annual minimum and maximum temperature in Tigray, 2008.

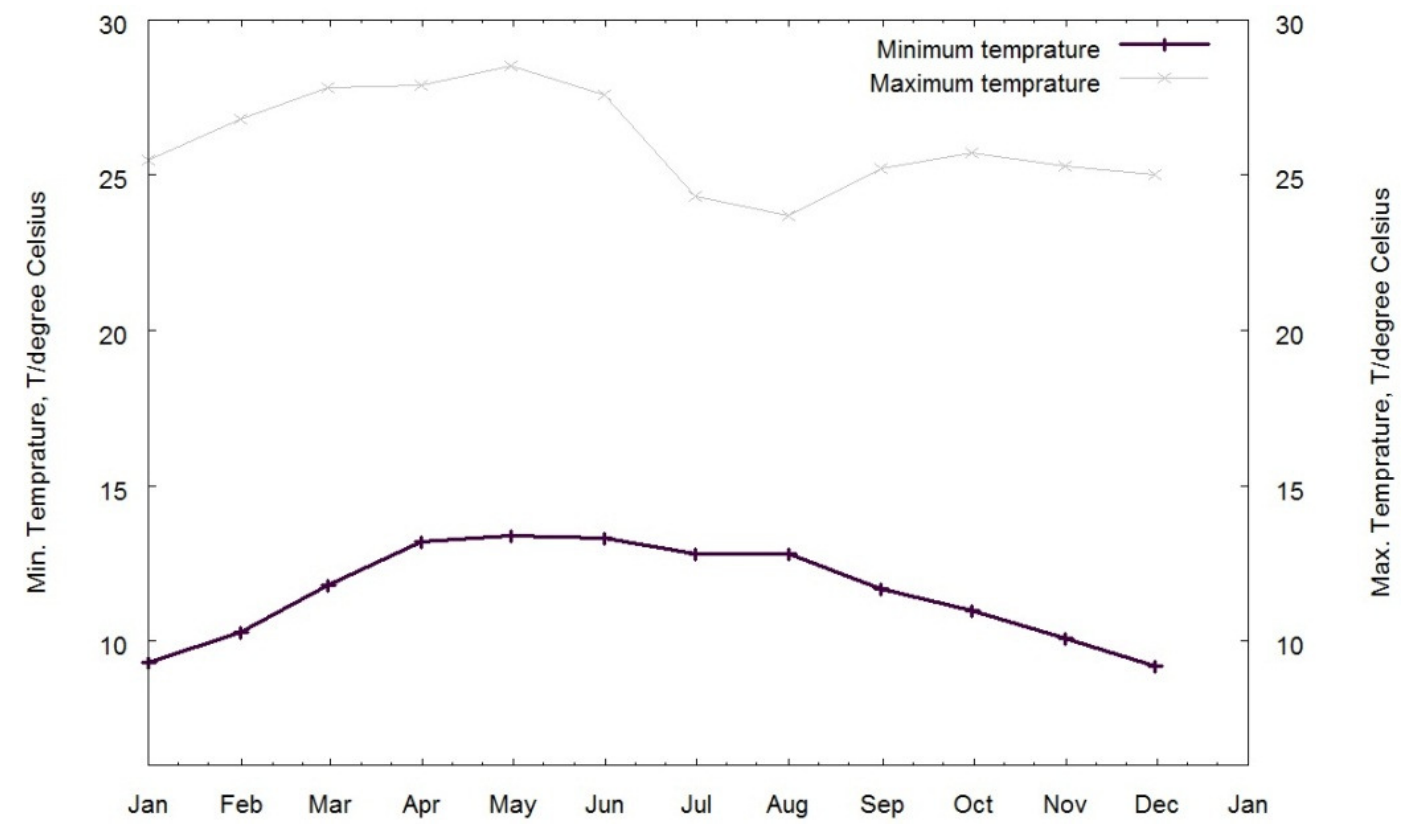

Figure 9. Inter-annual variability of monthly minimum and maximum temperature in Tigray, 1954-2008.

long- term average generally leads to a $4.4 \%$ reduction in the country's national food production. In this study, relationships between crop production and rainfall over the entire crop growing period were analysed using Pearson correlation coefficients.
Figure 12 displays a typical example of summer monsoon rainfall and food grain production relation in the study area. A $52.8 \%$ decline in food grains production from the preceding year was observed after an adverse agro-climatic condition faced by regional agriculture 


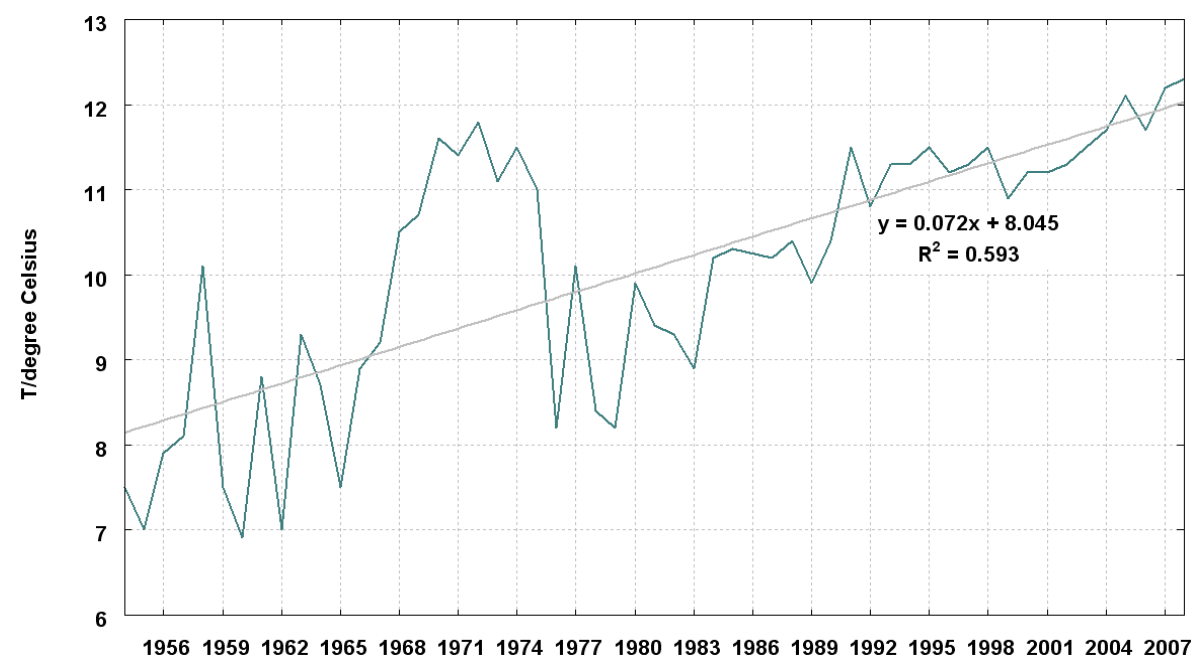

Figure 10. Year to year variability of annual minimum temperature in Tigray.

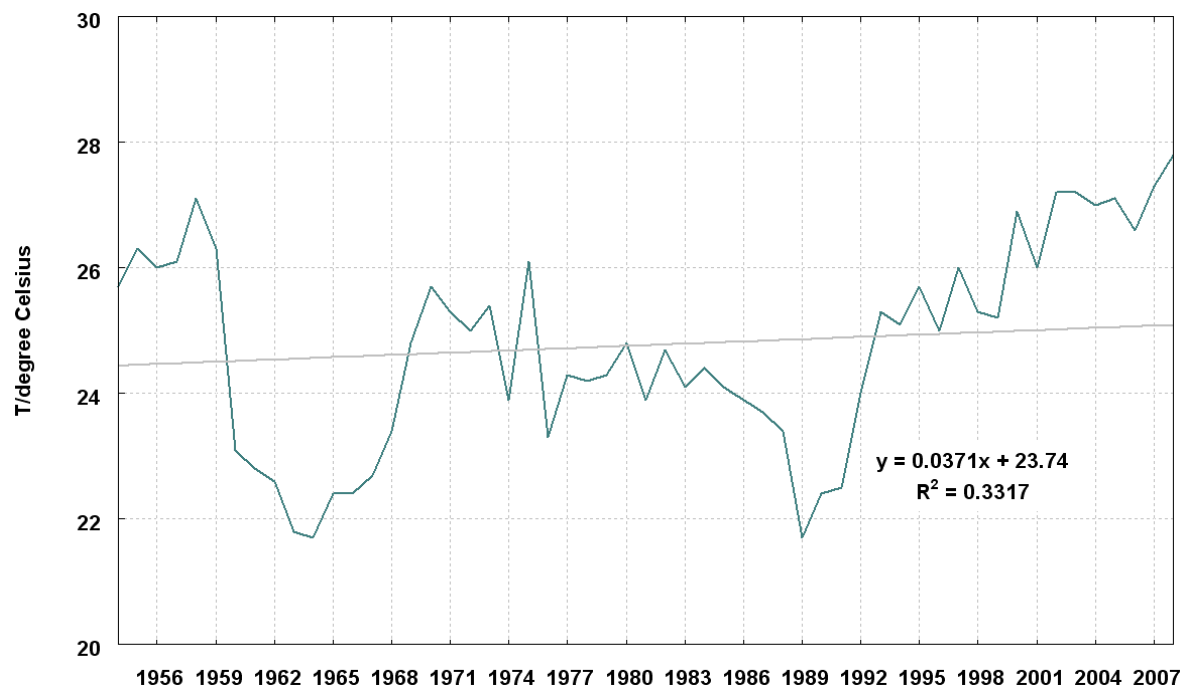

Figure 11. Year to year variability of annual maximum temperature expressed in temperature difference, Tigray.

due to a decline in monsoon rainfall in 2002. Visual estimation of the values from Figure $12 \mathrm{~b}$ gives a fairly strong correlation between summer rainfall and food grain production of 0.54 from $1992-2008$, and the cross correlation was found to be 0.41 when food grain production lags by 1 year. Besides, $52.2 \%$ of the variability in total food grain production anomalies is explained by summer monsoon rainfall.

\section{DISCUSSION}

In Tigray, precipitation is distributed very unevenly and is characterized by large spatial that is consistent with topographic difference. Smith (1979) reported that topography itself has a profound effect on spatial patterns of precipitation both globally and regionally. Considering annual rainfall variability, which directly affects agricultural production in parts of Ethiopia, the CV is found to be $37.7 \%$. This figure is high compared to the national figure of $8 \%$. This indicates that the distribution of long-term annual kiremti rainfall, the season where $80 \%$ of the crops produced, is characterized by large spatial variation. The annual and Kiremti rainfall are closely related since more than $70 \%$ of the rainfall comes during Kiremti season, but with quite large differences across the study area (Gebrehiwot et al., 2011).

As it is noted, meteorological drought indicates the deficiency of rainfall compared to normal rainfall in a given region. The temporal analysis of annual rainfall 

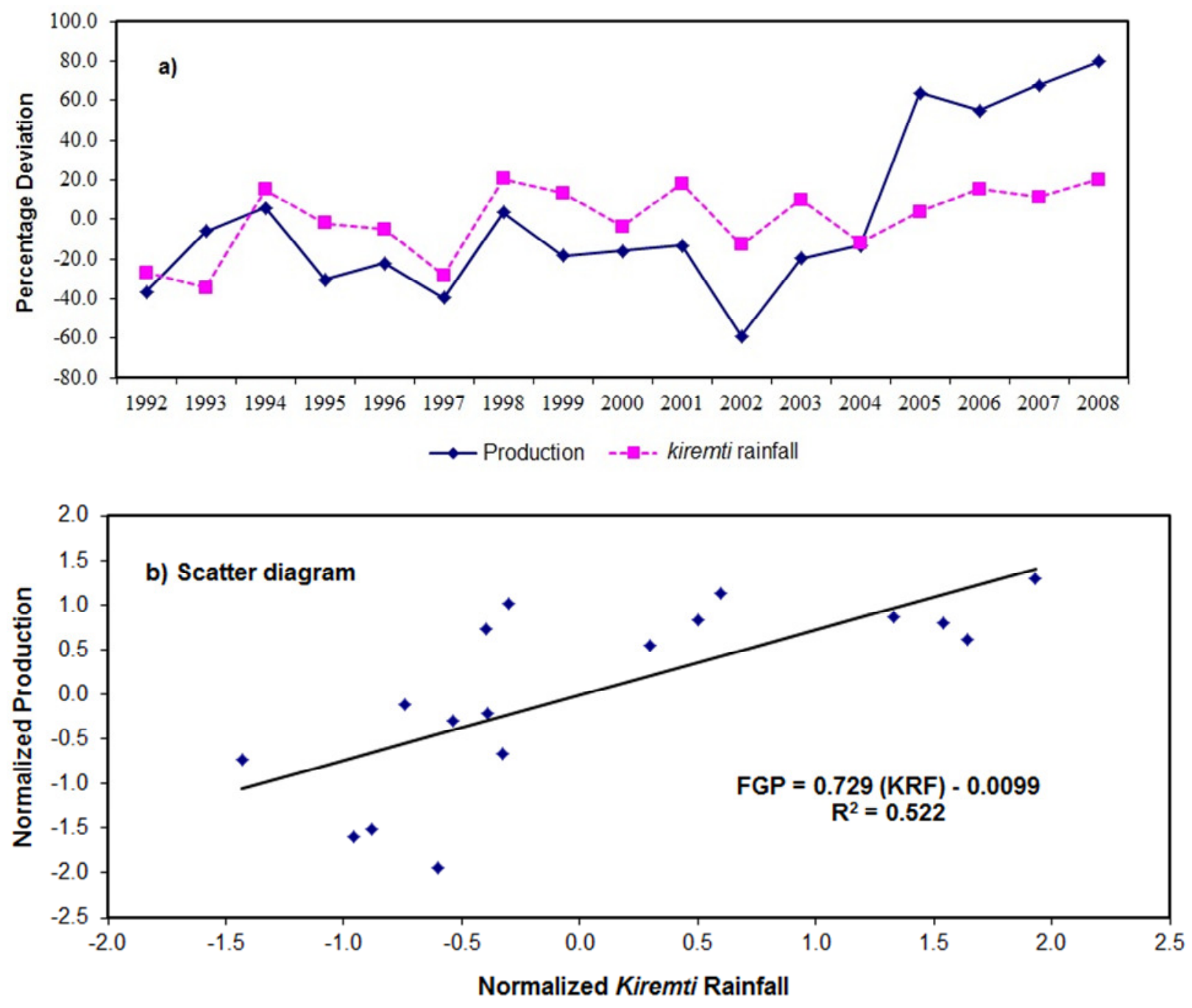

Figure 12. Relationship between kiremti rainfall (KRF) and total food grain production: (a) percentage deviation from average; (b) scatter diagram showing the relationship between normalized kiremti rainfall (KRF) and normalized total food grain production (FGP).

based on the standardized rainfall anomaly indicated that rainfall pattern in the study area exhibited a very high variability over time and is quite often accentuated with positive and negative anomalies. The analysis further revealed that rainfall was exceptionally low around the catastrophic years of 1964, 1973 and 1984. Beltrando and Camberlin (1993) reported the occurrences of repeated droughts in Ethiopia during 1973-1974 and 1982-1985, which badly affect the country and each time claiming the lives of several hundred thousands of people.

Similarly, the second half of the 20th century suffered predominantly negative anomalies, with kiremti (JuneSeptember) values frequently being lower than the longterm average. This variability assumes higher dimensions and for some parts, most notably the eastern and southern parts of the region, where inter-annual variability in rainfall has been significant often resulting in climate hazards, especially droughts with their devastating effects on food production and associated calamities and sufferings. Similarly, Krishnamurthy and Shukla (2000) analysed the inter-annual and intra-seasonal variability of summer monsoon rainfall over India and found that the major drought years are characterized by large-scale negative rainfall anomalies covering nearly all of India and persisting for the entire monsoon season. Trend analysis of annual rainfall based on the standardized rainfall anomaly generally indicates no marked emergent changes over the period 1954-2008 but shows a slight declining trend over the past few years. Meze-Hausken (2004) reported absence of declining trend in rainfall in the northern and north-eastern parts of Ethiopia. This was supported by Seleshi and Zanke (2004) who found no significant trend in the annual and seasonal rainfall totals in the central, northern and north western parts of the country over the period 1965-2002. 
The findings based on the definition of ENMSA indicated that the period 1979-1993 except for the year 1986 were characterized by rainfall shortage during the kiremti, which is the major rainy season in the study area. Furthermore, the analysis showed that persistent recurrence of precipitation shortfalls has prevailed since 1960, with major positive departures observed only in 1981, 1986, 1988, 1994, 1998, 1999, 2006 and 2007. By and large, the study area was predominantly characterized by negative rainfall deviations, with kiremti rainfall values frequently lower than the long-term average. This negative trend in seasonal rainfall was attributed to atmosphere-ocean interactions (Bewket and Conway, 2007).

According to the definitions of dry and very dry years of the ENMSA, the probability of a 'below-normal (poor)' rainfall year/spring/kiremti in the region is 22.6, 41.5 and $28.3 \%$, respectively. The probability of a 'much-belownormal (very poor)' rainfall year/spring/kiremti is 5.7, 15.1, and $11.3 \%$, respectively. It can be deduced from the analysis that since 1954 only the years $1961,1962,1966$, 1969, 1982 and 2008 would be classified as a 'muchbelow-normal' rainfall. It is thus visible that due to the abnormalities in monsoon precipitation in terms of both spatial and temporal distribution, drought is a frequent phenomenon over many parts of Tigray.

The findings of the ANOVA based on the 16 rainfall gauges indicated a high difference in CV across the stations, which indicated a high variability in rainfall amounts between the rainfall stations. The mean $\mathrm{CV}$ for the Kiremti (long rainfall season) is found to be smaller than that of the short rainfall season (March to April), implying the long rainfall season is more uniform than the short rainfall season. During the two rainfall periods, the coefficients of variation ranged between 15 and $49 \%$ for the long rains period, and 49 to $91 \%$ for the short rains period. This analysis of annual and seasonal rainfall variations has shown that annual rainfall variations are slightly higher; seasonal rainfall variations are higher (a bit more for the short rainfall season than for the long rainfall season) and monthly rainfall values have the highest variability. Similar findings are reported by MezeHausken (2004) that rainfall variability is highest for short rains as compared to the long rain for the northern Ethiopia. In contrast, Rosell (2011) found higher rainfall variability during the long rain season in the central highlands of Ethiopia for the period 1978-2007. The difference in the findings indicates the existence of large spatial variations in climate across the country.

The ANOVA analysis further indicated that the variability of mean monthly rainfall in the region is highly significant. This is so even for the wettest months of June to September and March to April. The variability of mean monthly rainfall during the drier months is significantly higher than the wet months. From this analysis, it is evident that the driest months are January, February, May, October, November and December. In general, the
ANOVA analysis showed that there is a significant difference in annual and Kiremti rainfall between meteorological stations, confirming the existence of spatial variations across stations in the study area.

The spatial analysis of drought frequency in the study area shows that the drought events have been geographically concentrated in the eastern and southern parts of Tigray. Tonini et al. (2012) and Gebrehiwot et al. (2011) also found that this part of Tigray is prone to a higher risk of drought. The test on the spatial clustering of drought frequency using Moran's Index further confirmed that nearby districts tend to have similar drought occurrence, implying that the frequency of drought shocks in the study area is unevenly distributed between the districts. It is thus visible that due to the abnormalities in monsoon precipitation in terms of both spatial and temporal distribution, drought is a frequent phenomenon in Tigray. As a result, farmers have experienced for many years the worst ill effect of drought in terms of loss of crops yield and livestock.

The year to year variation of annual minimum and maximum temperatures indicates that temperature in the study area has significantly increased over the period 1954-2008, in particular since the mid-1980s, the warming has accelerated. The instrumental record trend of mean annual minimum temperature over the study area reveals that significant temperature increase is very evident in the recent years. The statistical evidence suggested the study area has been getting hotter over the past five decades. The historical record further revealed that the average annual minimum temperature has been increasing by about $0.72^{\circ} \mathrm{C}$ every ten years while average annual maximum temperature has been increasing by about $0.37^{\circ} \mathrm{C}$ per decade. This shows that the study area is warming faster than the national average of $0.25^{\circ} \mathrm{C}$ per decade.

It is also interesting to note from the analysis that average annual minimum temperature is increasing faster than the average annual maximum temperature, which is clearly an indication of warming nights over the years. Similar finding was reported by Conway and Schipper (2011) and Strzepek and McCluskey (2006) who found that temperatures will continue to increase in Ethiopia over the coming years. Ben Mohamed et al. (2001) also reported a similar finding that a net warming trend is observed for minimum temperature since mid-1960s throughout the Sahel zone. Increase in average yearly temperatures by $0.13^{\circ} \mathrm{C}$ per decade is also observed in South Africa between the period 1960 and 2003 (Kruger and Shongwe, 2004).

The analysis on the association between crop yields and rainfall characteristics in the study area clearly shows the close relationship between the performance of agriculture and climate. The drought years were associated with a very low food grain production. For instance, food grains production during 2002 had slumped to 310.13 metric tonne (Mt), which is attributed 
to crop failure due to the severe drought which occurred all over the country. This indicates the vulnerability of the agricultural sector to the natural vagaries, which in turn shows the close association between inter-annual variations in kiremti rainfall (KRF) and total food grain production anomalies. This heavy dependency on rainfed agriculture renders the majority of farmers powerless in the face of irregular and unpredictable rainfall. Dercon and Krishnan (2000) reported that rainfall shocks, crop damage and livestock diseases are among the major shocks that make households vulnerable to poverty in rural Ethiopia. Similar relationship between major food crop yield and seasonal rainfall variability was observed in Kenya (UNDP, 2008).

By and large, the crop-climate relationship shows that annual total grain production was significantly associated with Kiremti rainfall. This reflects the potential impacts of any changes in rainfall patterns on agricultural production and thereby food security. Left unmanaged, climate variability can compromise the well-being of the people, particularly the rural farmers', whose livelihoods depend largely on rain-fed agriculture. Thus, due attention should be given to the issues of adaptation in the face of expected changes in climate and the issue of adaptation needs to be integrated into the development strategy of government policy. Particularly, farm level adaptation practices can greatly reduce vulnerability to climate change and climate variability by making rural communities better able to adjust to the changing climate. Thus, common agricultural adaptation strategies such as use of improved crop varieties and livestock species that are better suited to dry conditions, better and more efficient irrigation, diversifying crop varieties, adoption of mixed crop and livestock farming systems, and changing planting dates can be considered to counteract the negative impacts of the changing climate (Bradshaw et al., 2004; Kurukulasuriya and Mendelsohn, 2006; Onyeneke and Madukwe, 2010).

\section{Conclusion}

Given the fact that the study area is highly dependent on the agricultural sector for income and food security, erratic monsoon precipitation would adversely affect the lives perhaps of the majority of the population. Past experiences showed that it is getting harder and harder for households to bounce back from inconsistent weather affecting their livelihoods. Many have been forced to sell their assets, particularly livestock, as a coping mechanism that in turn increases the cycle of vulnerability. This study of precipitation and temperature enabled us to characterise and analyse the long-term spatial and temporal behaviour of rainfall and temperature in Tigray, northern Ethiopia.

The trend analysis on the significant climate parameters indicated a slight decrease in rainfall, and an overall increase in the mean annual minimum and temperatures in the study area. It is also observed that the increase in the minimum temperature is much higher than the increase in maximum temperatures, which is clearly an indication of warming nights over the years. This temperature increase will change the timing and amount of precipitation, and the availability of water. Furthermore, the warming temperatures and rainfall changes could diminish the availability of water for crops and shorten the growing season. The warming of a few degrees, decrease in rainfall and increase in frequency of extreme weathers, drought, will have an immediate and direct effect on the agricultural sector. As a result, the well-being of the people, particularly the rural farmers' whose livelihoods depend largely on rain-fed agriculture will be affected. Thus, the issue of adaptation should therefore be of a central concern to policy makers and needs to be integrated into the development strategy of government policy in order to counteract the negative impacts of the changing climate on agriculture.

\section{ACKNOWLEDGEMENTS}

The authors thank the editor and two anonymous referees for constructive comments and suggestions which have helped to improve the original version of the paper.

\section{REFERENCES}

Adger WN, Huq S, Brown K, Conway D, Hulme M (2003). Adaptation to climate change in the developing world. Prog. Dev Stud. 3:179-195.

Alexandrov VA, Hoogenboom G (2000). The impact of climate variability and change on crop yield in Bulgaria. Agric. Forest Meteorol. 104:315-327

Beltrando G, Camberlin P (1993). Interannual variability of rainfall in the Eastern Horn of Africa and indicators of atmospheric circulation. Int. J. Climatol. 13:533-546.

Ben Mohamed A, Van Duivenbooden N, Abdoussallam S (2001). Impact of climate change on agricultural production in the Sahelpart 1. Methodological approach and case study for millet. International Crops Research Institute for the Semi-Arid Tropics (ICRISAT), Andhra Pradesh, India.

Bewket W, Conway D (2007). A note on the temporal and spatial variability of rainfall in the drought-prone Amhara region of Ethiopia. Int. J. Climatol. 27:1467-1477.

Block P, Rajagopalan B (2007). Interannual variability and ensemble forecast of upper Blue Nile basin Kiremt season precipitation. Am. Meteorol. Soc. 8:327-343.

Boots B, Getis A (1998). Point pattern analysis. Sage Publications, Newbury Park, CA.

Bradshaw B, Dolan H, Smit B (2004). Farm-Level Adaptation to Climatic Variability and Change: Crop Diversification in the Canadian Prairies. Climatic Change 67:119-141.

Byerlee D, Spielman DJ, Alemu D, Gautam M (2007). Policies to promote Cereal Intensification in Ethiopia: A Review of Evidence and Experience. International Food Policy Research Institute. Development Strategy and overnance Division, Discussion Paper 00707.

Collier P, Conway G, Venables T (2008). Climate Change and Africa. Oxford Rev. Econ. Pol. 24:337-353.

Conway D, Mould C, Bewket W (2004). Over one century of rainfall and temperature observations in Addis Ababa, Ethiopia. Int. J. Climatol., 24:77-91. 
Conway D, Schipper ELF (2011). Adaptation to climate change in Africa: Challenges and opportunities identified from Ethiopia. Global Environ. Change 21:227-237.

Conway G (2008). The Science of Climate Change in Africa: Impacts and Adaptation. Department for International Development, UK.

CSA (2008). Summary and Statistical Report of the 2007 Population and Housing Census. Addis Ababa: Federal Democratic Republic of Ethiopia, Population Census Commission.

Datsenko NM, Sonechkon DM (1999). Refinement of time series of mean annual air temperature for the Northern and Southern Hemispheres in the 19th century Russ. Meteorol..Hydro., 10:17-22.

Dercon S (2004). Growth and Shocks: Evidence from Rural Ethiopia. J. Dev. Econ. 74:309-329.

Dercon S, Krishnan P (2000). Vulnerability, seasonality and poverty in Ethiopia. J. Dev. Stud. 36:25-53.

Deschênes O, Greenstone M (2007). The economic impacts of climate change: evidence from agricultural output and random fluctuations in weather. Am. Econ. Rev. 97:354-385.

Diao X (2010). Economic Importance of Agriculture for Sustainable Development and Poverty Reduction: The Case Study of Ethiopia. Global Forum on Agriculture 29-30 November 2010, Policies for Agricultural Development, Poverty Reduction and Food Security OECD Headquarters, Paris.

Dixon J, Gulliver A, Gibbon D (2001). Farming systems and poverty: improving farmers' livelihoods in a changing world, FAO and the World Bank, Rome, Italy and Washington, D.C.

Downing TE (Ed), (1996). Climate change and world food security.NATO ASI Series. Series I: Global Environmental Change 37. Springer-Verlag, Berlin, Germany.

Dracup JA, Lee KS, Paulson EGJ (1980). On the definition of droughts. Water Resour. Res. 16:297-302.

Easterling DR, Karl TR, Gallo KP, Robinson DA, Trenberth KE, Dai A (2000).Observed climate variability and change of relevance to the biosphere. J. Geophys. Res. 105:20101-120114.

ENMSA (2001). Initial National Communication of Ethiopia to the United Nations Framework Convention on Climate Change (UNFCCC), National Meteorological Services Agency (NMSA), Addis Ababa, Ethiopia.

Ferris-Morris M (2003). Planning for the Next Drought: Ethiopia Case Study USAID, Washington.

Fraser EDG (2007). Travelling in antique lands: using past famines to develop an adaptability/resilience framework to identify food systems vulnerable to climate change.Climatic Change, 83:495-514.

Funk C, Senay G, Asfaw A, Verdin J, Rowland J, Korecha D, Eilerts G, Michaelsen J, Amer S, Choularton R (2005). Recent drought tendencies in Ethiopia and Equatorial/Subtropical Eastern Africa. FEWS NET Report Number 01/2005.

Gebrehiwot T, van der Veen A, Maathuis B (2011). Spatial and temporal assessment of drought in the Northern highlands of Ethiopia. Int. J. Appl. Earth Obs. 13:309-321.

Haile M (2005). Weather patterns, food security and humanitarian response in sub-Saharan Africa. Phil. Trans. R. Soc. B. 360:21692182.

Heim RRJ (2000). Drought indices: A review. Drought, A Global Assessment, D. A. Wilhite, Ed., Routledge, London, 159-167.

Hellmuth ME, Moorhead A, Thomson MC, Williams J (2007). Climate Risk Management in Africa: Learning from Practice. International Research Institute for Climate and Society (IRI), Columbia University, 1-113.

Hulme M, Doherty R, Ngara T, New M, Lister D (2001). African climate change: 1900-2100. Clim. Res. 17:145-168.

IPCC (2001). Climate Change 2001: Impacts, Adaptation and Vulnerability, Contribution of Working Group II to the Third Assessment Report of the Intergovernmental Panel on Climate Change (IPCC). Cambridge University Press, Cambridge.

IPCC (2007a). Climate Change 2007: Impacts, Adaptation and Vulnerability, Summary for Policy makers, Working Group II Contribution to the IPCC Fourth Assessment Report of the Intergovernmental Panel on Climate Change. Cambridge University Press, Cambridge.

IPCC (Ed), (2007b). In: Solomon, S.D., et al. (Eds.), Climate Change2007: The Physical Science Basis. Contribution of Working
Group I to the Fourth Assessment Report of the Intergovernmental Panel on Climate Change. Cambridge University Press, Cambridge. Jones PD, Hulme M (1996). Calculating regional climatic time series for temperature and precipitation: Methods and illustrations. Int. J. Climatol. 16:361-377.

Keyantash J, Dracup JA (2002). The quantification of drought: An evaluation of drought indices. Bull. Am. Meteorol. Soc. 83:1167-1180.

Krishnamurthy V, Shukla J (2000). Intra-seasonal and Inter-annual Variability of Rainfall over India. J. Climate., 13:4366-4377.

Kruger AC, Shongwe S (2004). Temperature trends in South Africa: 1960-2003. Int. J. Climatol. 24:1929-1945.

Kurukulasuriya P, Mendelsohn R (2006). A Ricardian analysis of the impact of climate change on African crop land. CEEPA Discussion Paper No. 8. Centre for Environmental Economics and Policy in Africa. Pretoria, South Africa: University of Pretoria.

McCarthy JJ, Canziani OF, Leary NA, Dokken DJ, White KS (2001). Climate change 2001: Impacts, Adaptation, and Vulnerability: contribution of Working Group II to the third assessment report of the Intergovernmental Panel on Climate Change. Cambridge University Press, Cambridge. p. 499

McKee TB, Doesken NJ, Kleist J (1993). The relationship of drought frequency and duration to time scales. In: Proceedings of eighth conference on applied climatology, Anaheim, California, 17-22 January.

Meze-Hausken E (2004). Contrasting climate variability and meteorological drought with perceived drought and climate change in northern Ethiopia. Clim. Res. 27:19-31.

Onyeneke RU, Madukwe DK (2010). Adaptation measures by crop farmers in the southeast rainforest zone of Nigeria to climate change. Sci. World J. 5:32-34.

Palmer WC (1965). Meteorological drought. Research Paper No. 45, U.S. Weather Bureau, Washington, D.C., p. 58.

Parry ML, Rosenzweig C, Iglesias A, Livermore M, Fischer G (2004). Effects of climate change on global food production under SRES emissions and socio-economic scenarios. Global Environ. Change 14:53-67.

Peterson TC, Gallo KP, Lawrimore J, Owen TW, Huang A, McKittrick DA (1999). Global rural temperature trends.Geophys. Res. Lett. 26:329-332.

Rosell S (2011). Regional perspective on rainfall change and variability in the central highlands of Ethiopia, 1978-2007. Appl. Geogr., 31:329-338.

Sarah TL (2002). Climate change and poverty, Tearfund, Teddington, Middlesex TW11 8QE, UK.

Seleshi Y, Zanke U (2004). Recent changes in rainfall and rainy days in Ethiopia. Int. J. Climatol. 24:973-983

Smith RB (1979). The influence of mountains on the atmosphere. Adv. Geophys. 21:87-233.

Steel RGD, Torrie. JH (1981).Principles and Problems of Statistics.Second Edition.McGraw-Hill Publishers, Singapore.

Strzepek K, Mccluskey A (2006). District level hydro-climatic time series and scenario analysis to assess the impacts of climate change on regional water resources and agriculture in Africa. CEEPA Discussion Paper 13. Centre for Environmental Economics and Policy in Africa, University of Pretoria.

Tate EL, Gustard A (2000). Drought definition: a hydrological perspective, In Vogt J.V. and F.Somma (ed). Drought and Drought mitigation in Europe. Kluwer Academic Publishers, the Netherlands. pp. 23-48.

Tebaldi C, Hayhoe K, Arblaster JM, Meehl GA (2006).Going to extremes. An intercomparison of model-simulated historical and future changes in extreme events.Clim. Change 79:185-211.

Tonini F, Lasinio GJ, Hochmair HH (2012). Mapping return levels of absolute NDVI variations for the assessment of drought risk in Ethiopia. Int. J. Appl. Earth Obs. 18:564-572.

UNDP (2008). Climate Change and Human Development in Africa: Assessing the Risks and Vulnerability of climate Change in Kenya, Malawi and Ethiopia. Human Development Report 2007-08. United Nations Development Programme (UNDP), Intergovernmental Authority on Development and the Climate Prediction and Applications Centre.

van der Veen A, Tagel G (2011). Effect of policy interventions on food 
security in Tigray, Northern Ethiopia. Ecol. Soc., 16:1-17.

Van Rooy MP (1965). A rainfall anomaly index independent of time and space. Notos 14:43-48.

Watson R, Zinyowera M, Moss R (Eds.) (1996). Climate Change 1995 - Impacts, Adaptation and Mitigation of Climate Change. Contribution of WG II to the Second Assessment Report of the IPCC, Cambridge University Press, Cambridge. p. 6

Watson RT, Zinyowera MC, Moss RH (1998). The regional impacts of climate change: An assessment of Vulnerability, Cambridge University Press pp. 1-18.

Webb P, von Braun J, Yohannes Y (1992). Famine in Ethiopia: Policy implications of coping failure at national and household levels. International Food Policy Research Institute, Washington, DC. pp. 65-66.
Wilhite D, Glantz M (1985). Understanding the drought phenomenon: the role of definitions. Water Int., 10:111-120.

Wilhite DA (2000). Drought as a natural hazard: Concepts and definitions. Droughts: A Global Assessment, D. A. Wilhite, Ed., Routledge, pp. 3-18. 